Radosław Kuliniak

Uniwersytet Wrocławski, Wrocław

ORCID: 0000-0002-0090-6609

e-mail: kornik90@poczta.onet.pl

Mariusz Pandura

Uniwersytet Wrocławski, Wrocław

ORCID: 0000-0001-5875-2705

e-mail: mariusz.pandura@uni.wroc.pl

\title{
Zbiory Romana Witolda Ingardena w Archiwum Rodzinnym Ingardenów (zarys problemu)
}

Wielkim, szczęśliwie zrealizowanym marzeniem Romana Witolda Ingardena było posiadanie własnego gabinetu ${ }^{1}$. Centralne miejsce zajmowało $\mathrm{w}$ nim dębowe biurko $\mathrm{z}$ dużym pulpitem, szufladami oraz różnymi skrytkami, które znał jedynie jego właściciel. Dalej trzeba wymienić dobrej marki maszynę do pisania, element konieczny w tamtych czasach, nie dany jednak każdemu, a przez Ingardena traktowany ze szczególną starannością, często zabierany w liczne podróże, co oczywiście wiązało się z pewną niewygodą. Były tam również wiszące na ścianach portrety: ukochanej żony Nuny, Edmunda Husserla, Maxa Schelera i Edith Stein. W gabinecie filozofa znajdowały się ponadto regały i witryny zabezpieczające zbiory przed wszędobylskim kurzem. Obok książek były w nich złożone manuskrypty, których wraz z upływem czasu przybywało coraz więcej. Dziś, w dobie komputerów, Ingarden zastąpiłby je pewnie

${ }^{1}$ Autorzy wyrażają serdecznie podziękowania Pani Dr Ricie Majkowskiej za krytyczne uwagi dotyczące tekstu. 
folderami mieszczącymi poszczególne dokumenty. Trudno sobie bowiem wyobrazić, by w dzisiejszych czasach ktoś mógł gromadzić sterty papieru, który często żółknie i płowieje. Ostatnimi ważnymi elementami w gabinecie filozofa były oczywiście wygodny fotel i kanapa, z której Ingarden zrezygnował z powodu panującej w pomieszczeniu ciasnoty.

Tak w ogólnym zarysie wyglądało jego miejsce pracy, nad którym zawsze unosiła się chmura dymu papierosowego. Panująca tam atmosfera była więc duszna, jednak sprzyjała intelektualnym wysiłkom Ingardena. Nie o tym jednak chcemy pisać. Bardziej interesuje nas bowiem zawartość regałów i szaf, a mianowicie złożone w nich książki oraz manuskrypty. Wspomnijmy jeszcze, że Ingarden nie zawsze miał własny gabinet. Wszedł $\mathrm{w}$ jego posiadanie dopiero po przenosinach z Warszawy do Torunia w 1921 roku. To właśnie tam, wraz z rozpoczęciem nowego roku szkolnego, w mieszkaniu przy Mickiewicza 115 zasiadł po raz pierwszy w swoim fotelu.

\section{Księgozbiór Romana Witolda Ingardena}

Książki w życiu Ingardena odgrywały szczególną rolę. Nie budował on jednak swojej biblioteki w celach kolekcjonerskich. Książki były bowiem podstawą jego warsztatu naukowego. Gomadził je namiętnie i traktował ze szczególną troską. Poszczególne egzemplarze miały wklejone ekslibrisy z nadrukiem „Ex libris Romana Ingardena”. Niemal każdy z nich ma swoją historię. Zanim znalazły się na półkach, w szafie lub regale, zostały przestudiowane z głębokim namysłem. Nie ma w bibliotece Ingardena książki, która nie byłaby opatrzona osobnym komentarzem. Filozof czynił swoje notatki na kartach poszczególnych książek, tworząc niekiedy obszerne scholia. $W$ jego archiwaliach znajdują się również liczne zeszyty, w których fenomenolog zapisywał to, co czytał w danej chwili. Sporządzał też Ingarden charakterystyczne, długie notatki, omówienia, streszczenia i komentarze do swoich lektur. Wnuk filozofa Krzysztof Ingarden pokazał nam kiedyś kolejne wydania niemieckie Das literarische Kunstwerk i Intuition und Intellekt bei Henri Bergson. Z pozoru nie różniły się one od pozostałych książek. Po sięgnięciu do nich okazało się jednak, że były to egzemplarze specjalnie przygotowane dla Ingardena przez Wydawnictwo Niemeyera. Pozycje różniły się od wydawanych klasycznie książek tym, że prawe strony zawierały tekst dzieła, a lewe były zupełnie puste. $Z$ czasem Ingarden, czytając po raz wtóry swoje prace, zapisywał puste karty uwagami uzupełniającymi. Taki sposób czytania i komentowania własnych oraz cudzych prac towarzyszył mu od wczesnej młodości. Jeszcze w Getyndze, gdy po dwutygodniowym oczekiwaniu na zamówione $\mathrm{w}$ uniwersyteckiej uczelni Logische Untersuchungen Husserla mógł wreszcie zapoznać się z tym dziełem, korciło 
go, aby zapisać własne spostrzeżenia na czytanym przez siebie egzemplarzu. Ten sposób można - a nawet trzeba - polecić każdemu, kto chce nauczyć się filozofii. Czytajmy, zapisujmy i komentujmy za każdym razem to, co czytamy. Róbmy uwagi i wracajmy do nich, a wyuczymy się na wielkich filozofów, takich jak Ingarden!

Biblioteka Ingardena nie była tylko jego dziełem. W jej tworzeniu brała udział również jego ukochana żona Nuna. Jednak to Ingarden zaczął tworzyć księgozbiór, który powstawał w latach spędzonych przez fenomenologa $w$ gimnazjum we Lwowie, a został rozbudowany później, podczas studiów filozofa we Lwowie, w Getyndze i we Fryburgu. W czasach warszawskich, toruńskich i lwowskich biblioteka małżeństwa Ingardenów rozrosła się do znacznych rozmiarów. Trzeba było dostawiać - już nie tylko w gabinecie filozofa - kolejne regały i szafy. Gromadzone książki powoli zaczęły stawać na drodze przyjemności, którą czerpano z ich lektury. Oboje małżonkowie często gubili się w swoim zbiorze. Dlatego Ingarden, za namową żony, przystąpił do skatalogowania zgromadzonego zbioru. W ten sposób powstał katalog, a dokładnie „Spis książek Marii i Romana Ingardenów”. Jest on złożony w zbiorach rodzinnych. Liczy sobie dwieście dwadzieścia pięć stron i trudno go zaprezentować w całości. Niemniej jednak warto przyjrzeć się ogromnej pracy, którą filozof sumiennie wykonywał przez niemal wszystkie lata swojego życia.

Katalog książek małżeństwa Ingardenów w większości obejmuje woluminy będące $w$ centrum zainteresowania fenomenologa. Tomy o tematyce $\mathrm{z}$ kręgu fachowych zainteresowań Marii Ingardenowej znajdują się w zestawieniu, lecz jest ich niewiele. Spis ma charakterystyczną strukturę. W jego początkowej części widać trzy ślady układów o zachowanym porządku alfabetycznym. Są to:

1. Spis 1: alfabetyczny spis książek filozoficznych, obejmujący pozycje 1-61 kompletnego zestawienia.

2. Spis 2: alfabetyczny spis książek niefilozoficznych (głównie poezja, literatura piękna, literaturoznawstwo, fizyka i matematyka), obejmujący pozycje 62-102, wraz z dodaną niealfabetycznie pozycją 103.

3. Spis 3: alfabetyczny spis książek filozoficznych i niefilozoficznych, obejmujący pozycje 104-210.

Spis pierwszy powstał najprawdopodobniej przed 1922 rokiem. Najpóźniejsza data, jaka w nim występuje, to rok 1921. Jest ona zaświadczona w zapisach: „29. Husserl E., Logische Untersuchungen II. A., Halle, 1913-21" oraz „31. Husserl E., Jahrbuch f. Philosophie u. phaenomenologische Forschung I-IV, Halle, 1913-1921, 4 [vols.]". Pierwotnie jednak $\mathrm{w}$ spisie najprawdopodobniej nie znalazły się ostatnie tomy danej pozycji, a jedynie egzemplarze wcześniejsze. Potwierdzenie tego faktu widzimy w późniejszej partii zestawienia, gdzie tom czwarty "Jahrbuchu" został ponownie zarejestrowany pod numerem 220. Kiedy 
więc pominiemy te dwa wspomniane zapisy dotyczące 1921 roku, okaże się, że najstarszą datą pojawiającą się w spisie pierwszym jest 1919 rok („10. Bergson H., L'Energie spirituelle, Paris, 1919” oraz „50. Platon, Eutyfron, Obrona Sokratesa, Kriton, Lwów, 1919"). Pozwala to na ostrożne datowanie spisu pierwszego na rok 1919.

Najpóźniejszą datą widniejącą w spisie drugim jest rok 1919. Pojawia się przy pozycji „106. Askenazy Sz., Gdańsk a Polska, Warszawa, 1919”. Brak natomiast w tej części zestawienia wymienionej książki późniejszej. Dlatego też należy spis drugi datować najprawdopodobniej także na rok 1919. Komplementarność spisu pierwszego i drugiego - jeden rejestrował część filozoficzną księgozbioru, drugi pozafilozoficzną - pozwala przypuszczać, że oba rejestry powstały w tym samym czasie.

W przeciwieństwie do nich spis trzeci powstał zapewne nieco później. Zarejestrowane są w nim dwie pozycje wydane w roku 1920: „208. Żeromski Stefan, Sułkowski, Warszawa, 1920" oraz "Żeromski Stefan, Ponad śnieg bielszy, Warszawa, 1920". Ma on także układ alfabetyczny, lecz nie obowiązuje w nim podział na książki filozoficzne i inne - obie grupy występują łącznie. Na podstawie tego można wnioskować, że spis ten nie powstał $w$ tym samym czasie, co dwa poprzednie rejestry. Został sporządzony najprawdopodobniej w 1920 roku. W żadnym z tych spisów nie znajdujemy książek okulistycznych, które pojawiają się w kolejnych partiach zestawienia. Z powyższych uwag wnioskujemy, iż zaraz po zawarciu małżeństwa z Marią Adelą Józefą Pol, zwaną przez wszystkich domowników Nuna, w 1919 roku Ingarden przeprowadził spis już posiadanych przez siebie książek, wyróżniając w nim osobno książki filozoficzne. Po roku wpisał wszystkie nowo nabyte książki w odrębnym spisie stanowiącym kontynuację poprzedniego.

Dalsza, najobszerniejsza część spisu, obejmująca pozycje 211-4609, ma inny charakter. Jest to zarówno inwentarz księgozbioru, jak i de facto rejestr nabytków. Filozof odnotowywał w nim kolejno otrzymywane i kupowane książki, które znalazły miejsce na jego regałach. Wśród najstarszych pozycji zarejestrowanych w tej części znajdujemy głównie prace z 1921 roku (choć pojawiają się i starsze), następnie zaczynają dominować te z 1922 roku, później z 1923 roku i lat kolejnych aż po rok 1970. Ta partia zestawienia jest doskonałym źródłem uzupełniającym do biografii Ingardena, gdyż pozwala nam choćby częściowo wskazać, jakie książki fenomenolog pozyskiwał w kolejnych latach. Już w najwcześniejszych partiach tej części pojawiają się książki Marii Ingardenowej, np. „226. Kramsztyk Z., Objawy kliniczne chorób oczu, Warszawa, Mianowski 1907” czy „275. Żebrowski A., Zarys otiatrji, Warszawa, 1921”. Ostatnią pozycją jest „4609. Husserl Edmund, Philosophie der Arithmetik, Den Haag, 70, 1”, przy której naniesiono adnotację „8. 8. 70”. Data ta zapisana została już po śmierci fenomenologa i wskazywała stan liczbowy księgozbioru na ów dzień. 
Bezpośrednio po tej części następują odręcznie zapisane uwagi syna filozofa, Romana Stanisława, dotyczące lokalizacji woluminów z księgozbioru fenomenologa. Z zestawienia wynika, że 8 sierpnia 1970 roku w Krakowie powinny znajdować się 3723 tytuły (w 4158 tomach), natomiast we Lwowie pozostało 886 tytułów (w tyluż tomach). Oprócz tego Roman Stanisław nanosił w kolejnych tygodniach także informacje dotyczące tego, ile książek z księgozbioru ojca przewiózł do Torunia, gdzie wówczas mieszkał. Mianowicie pod datą „23.8.70” widnieje zapis: "powinno być w Krakowie 3431", a pod datą "22.11.70”: „zabrano do Torunia 35 dzieł w 41 teczkach".

Kolejna część spisu, numery 4610-4649, spisana niewątpliwie już po śmierci fenomenologa, rejestrowała książki z jego księgozbioru, które uprzednio nie były odnotowane i na których nie zapisano odpowiednich numerów. Wraz z ich rejestrowaniem naniesiono na nie numerację. Były to głównie nadbitki, choć nie brakowało wśród nich takich pozycji, jak Signes Merleau-Ponty'ego czy polskie tłumaczenie Idei Husserla. W kolejnej partii, obejmującej numery 4650-4678, zarejestrowano czasopisma z księgozbioru fenomenologa, których dotychczas nie odnotowano w spisie (czyli większość). Zdecydowano, iż każdemu tytułowi czasopisma odpowiada jedna sygnatura, pod którą zapisywano poszczególne numery. Następnie zinwentaryzowano pod numerami 4679-4975 (błędnie, ostatnia pozycja powinna nosić numer 4795) różne książki, w przeważającej mierze polskie. Wreszcie ostatnią partię spisu książek Marii i Romana Ingardenów obejmuje zestawienie „Uzupełnienia (czasopisma dopisane do sygnatur spisu Profesora)". Wymienione są w nim sygnatury czasopism już spisane wcześniej, wraz z późniejszymi nabytkami woluminów, które w tym momencie zdecydowano się dopisać.

W książki fenomenolog wklejał wspomniany już ekslibris. Oprócz tego nanosił na nie adnotacje rejestrujące sygnaturę: "No I[nwentarzowy] ...". W niektórych starszych książkach znajdujemy także odręcznie zapisane na stronach tytułowych nazwisko "Ingarden” oraz rok pozyskania (np. „1921”, „1924”). Niekiedy także widzimy wypełnione odręcznie standardowe druki karty książki ze spisanym nazwiskiem autora, tytułem, sygnaturą. Prócz tego część książek została przyporządkowana do działów tematycznych. Adnotacje dotyczące działów znajdują się zarówno w spisie, bezpośrednio na książkach, jak i na kartach książki. Działy były następujące: „Kl” (klasycy filozofii, np. Arystoteles, Spinoza, Fichte, Schopenhauer), „N” lub „Niem.” (filozofia niemiecka), „Fr" (filozofia francuska), „P" (filozofia polska), „F" (fenomenologia), "X" (inne nauki, głównie psychologia i literaturoznawstwo), "A" (filozofia angielska), „,Cz" (czasopisma filozoficzne), „E” (estetyka), „I" (filozofia innych krajów: między innymi marksistowska filozofia radziecka), „S” (leksykon filozoficzny), „K" (kongresy). Nie ma jednak pewności, 
czy adnotacje dotyczące działów zostały wprowadzone przez Romana Witolda, czy też przez Romana Stanisława.

Znamy też dalszą historię księgozbioru Ingardena. Duża część książek została jeszcze w 1970 roku przekazana przez żonę Nunę do Biblioteki Polskiej Akademii Nauk w Krakowie. Jedynie niewielka część najważniejszych książek pozostała w posiadaniu rodziny. Kolekcja przekazana do Biblioteki PAN znalazła się tam ostatecznie w liczbie 3015 woluminów, z tego wśród druków zwartych i wydawnictw ciągłych było 1170 woluminów publikacji krajowych i 1845 woluminów publikacji zagranicznych ${ }^{2}$. Nie uległa ona rozproszeniu i stanowi dziś nie tylko zwarty zbiór książek, którym można by było zapełnić niejedną bibliotekę filozoficzna, lecz jest również przykładem wzorowo prowadzonej pracy archiwizacyjnej. Daje ponadto możliwość poznania warsztatu naukowego Ingardena. Czytając zgromadzone przez fenomenologa książki, a zwłaszcza zapiski marginesowe w nich poczynione, można odkryć niejedną ważną tajemnicę filozoficzną którą Ingarden ukrył przed światem.

\section{Manuskrypty Romana Witolda Ingardena}

W gabinecie Ingardena obok książek znajdowały się manuskrypty i maszynopisy jego prac. Przez wszystkie lata życia filozofa były poddawane nie lada próbie przetrwania. Szczęśliwie dziś, po dwóch wojnach światowych i tułaczkach między Lwowem, Krakowem i Toruniem, znajdują się niemal w całości w depozycie Archiwum Nauki PAN i PAU w Krakowie.

Losy manuskryptów Ingardena, jak wspomnieliśmy, podlegały licznym próbom przetrwania. Sam filozof przywiązywał do swoich prac ogromną wagę. Po II wojnie światowej w Krakowie trzymał je w dwóch szafach w swoim gabinecie przy Biskupiej 10. Jak wynika z jego zapisków (zwłaszcza z jednego, ze spisu odręcznie dokonanego przez filozofa najprawdopodobniej trzy lata przed śmiercią), szafy były dwie: 1) „prawa, od dołu i od góry, a także od środka” oraz 2) „lewa, od dołu i od góry". Ingarden układał w nich swoje manuskrypty w sposób systematyczny. Nie gromadził tekstów, które uważał za ważne lub mniej ważne. Wszystkie traktował jednakowo. Zachowały się także: a) materiały osobiste, tj. dzienniki, listy rodzinne, poezja młodzieńcza i próby literackie, odznaczenia, materiały przodków itd.; b) zapiski z lektur, spisy bibliograficzne prac cudzych, a także ogromna ilość notatek do

2 Zob. Zbigniew Jabłoński, „Sprawozdanie z działalności Biblioteki Polskiej Akademii Nauk w Krakowie za okres od 1 I-31 XII 1970", Rocznik Biblioteki Polskiej Akademii Nauk w Krakowie, R. 16 (1970, wyd. 1971): 275-289. 
wykładów, zapiski z wykładów osób drugich, zapiski z dyskusji, szpule magnetofonowe z zapisem dyskusji i wykładów filozofa; c) teczki i księga rachunkowa z prowadzonego przez filozofa czasopisma Studia Philosophica; są wreszcie d) liczne rękopiśmienne prace oraz ich kopie, recenzje prac doktorskich, habilitacyjnych oraz opinie w sprawie postępowań awansowych.

Wspomniany zbiór manuskryptów podlegał katalogowaniu. Filozof dokonał co najmniej pięciu spisów swoich prac. Skatalogował też listy.

Pierwszy zachowany spis rękopiśmiennych prac Ingardena powstał we Lwowie w 1928 roku. Został dokonany w kwietniu tegoż roku zaraz po powrocie filozofa ze stypendium paryskiego, połączonego $\mathrm{z}$ odwiedzinami Husserla we Fryburgu, wykładami Heideggera w Marburgu i wycieczką z Edith Stein do Bergzabern do „Domu Fenomenologów”, prowadzonego przez małżeństwo Conradów. Nadmieńmy, że filozof wcześniej starał się dwukrotnie o ten wyjazd, a podróż paryską odbył $\mathrm{w}$ dość nieciekawym dla siebie momencie. Było to tuż po przegranej batalii z Kazimierzem Ajdukiewiczem o III Katedrę Filozofii we Lwowie. W 1928 roku Ingarden powracał do Lwowa dość niechętnie. Musiał skrócić swój pobyt z powodu choroby żony i synów. Również na uniwersytet wracał z pewnymi obawami. Rządził tam wszechwładny tandem teść-zięć, tzn. Twardowski wraz z Ajdukiewiczem. Zaraz po przyjeździe do Lwowa Ingarden zasięgnął opinii Wartenberga o sytuacji panującej we lwowskiej filozofii. Szybko spostrzegł, że szans na awans naukowy nie ma na razie żadnych. Oddalił się więc od zatęchłego środowiska i skupił uwagę na rozwoju naukowym. Pierwszym ku temu krokiem był gruntowny remanent $\mathrm{w}$ papierach. Jego rezultatem okazał się "Spis nieogłoszonych prac, szkiców i notatek". Ingarden usystematyzował dzięki niemu swoje badania. Powrócił do starych, niedokończonych prac. Uzupełnił ponadto swoje manuskrypty o materiały przywiezione z eskapady paryskiej. Sporządzony spis pozwolił mu wyjść na prostą $\mathrm{w}$ jego badaniach. Po zakończeniu inwentaryzacji filozof przystąpił do dalszych badań w uporządkowanym gabinecie.

Kolejne spisy bibliograficzne, zawierające wykaz prac publikowanych i niepublikowanych przez Ingardena, pochodzą z okresu II wojny światowej. Był to dla filozofa czas bardzo smutny i intensywny pod każdym względem. Ingarden żył wraz z rodziną we Lwowie w ciągłym niepokoju. Niepewność jutra łączyła się nie tylko z pracą $\mathrm{w}$ tajnych kompletach, ale także z posiadaniem maszyny do pisania, księgozbioru i manuskryptów. W obawie przed aresztowaniem, więzieniem, zesłaniem, a nawet rozstrzelaniem filozof postanowił dokonać trzech spisów swoich prac w celu oddania ich w depozyt do Lwowskiego Ossolineum. Wcześniej, tuż przed wybuchem wojny, znalazła się w innych bibliotekach spuścizna po Twardowskim, a także materiały z Polskiego Towarzystwa Filozoficznego i innych agent wydawniczych prowadzonych 
przez Twardowskiego i jego uczniów we Lwowie. Nie były one dostatecznie zabezpieczone i po wejściu okupanta radzieckiego do Lwowa uległy rozproszeniu. Ingarden wiedział o tym. Niemniej zdecydował się na oddanie w depozyt swoich manuskryptów, listów i księgozbioru. Wszystkie te spisy zawierają podpisy osoby przyjmującej depozyt, Stefana Inglota, późniejszego profesora historii oraz dziekana Wydziału Historyczno-Filozoficznego Uniwersytetu Wrocławskiego. Inglot pełnił od 13 stycznia 1940 roku, w zastępstwie chorego Kazimierza Tyszkowskiego, obowiązki kierownika Oddziału Rękopisów w Ossolineum³, wkrótce przekształconego w Lwowską Filię Biblioteki Akademii Nauk USRR przy ul. Ossolińskich 2. Kilka miesięcy później, 15 kwietnia 1940 roku, dwa dni po aresztowaniu Rudolfa Kotuli, Inglot przejął także - z polecenia swoich zwierzchników, Jakowa Zajkina i P. I. Samiłowa - opiekę nad zbiorami Biblioteki Baworowskich i często tam przebywał ${ }^{4}$. To właśnie 15 kwietnia doszło do pierwszego przekazania przez Ingardena swoich zbiorów do Ossolineum, na ręce Inglota. Wydaje się, że były one przechowywane właśnie w Bibliotece Baworowskich, gdzie zgromadzono już część nowych nabytków rękopiśmiennych, a przez pewien czas planowano tam także przenieść cały Oddział Rękopisów ${ }^{5}$. W każdym razie później, w 1945 roku, zbiory Ingardena miały zostać odebrane przez syna filozofa, Romana Stanisława, z Biblioteki Baworowskich.

Przekazując Inglotowi swoje zbiory, Ingarden zastrzegł sobie możliwość ich odebrania w każdej chwili, w której uzna to za stosowne. W tamtym czasie powstały następujące spisy: a) „I. Rękopisy niedrukowane”; b) „II. Spis rękopisów prof. R. Ingardena przekazanych Bibliotece Ossolineum we Lwowie”; c) „III. Spis rękopisów prof. Romana Ingardena

3 Zob. S. Inglot, Brudnopis „Sprawozdania z pracy [Oddziału Rękopisów] w miesiącu styczniu 1940 [roku]", Львівська національна наукова бібліотека України імені В.Стефаника ім. В. Стефаника. Відділ рукописів, ф. 54, оп. 2, од. зб. 84, s. 54; Maciej Matwijów podaje, że Inglot przejął obowiązki w poniedziałek 15 stycznia (zob. Maciej Matwijów, Zakład Narodowy imienia Ossolińskich w latach 1939-1946, Warszawa: Towarzystwo Przyjaciół Ossolineum, 2003, 58). Zob. także Paweł Sierżęga, Kazimierz Tyszkowski (1894-1940). Z dziejów nauki polskiej w międzywojennym Lwowie (Rzeszów: Wydawnictwo Uniwersytetu Rzeszowskiego, 2011), 361.

${ }_{4}$ Zob. Stefan Inglot, Brudnopis „Sprawozdania z czynności pracowników Oddziału Rękopisów filii Biblioteki Akademii Nauk U. S. R. R. przy ulicy Ossolińskich 2 za miesiąc kwiecień [1940 roku]", Львівська національна наукова бібліотека України імені В.Стефаника. Віддія рукописів, ф. 54, оп. 2, од. зб. 84, 374. Zajkin był ówczesnym dyrektorem Lwowskiej Filii Biblioteki AN USRR. O Samiłowie zob.: Tadeusz Mańkowski, Biblioteka Ossolineum w latach 1939-1944, w: Zakład Narodowy im. Ossolińskich, sygn. rkps. 17061/II, 14; Tadeusz Mańkowski, „Ossolineum pod rządami sowieckimi", oprac. Maciej Matwijów, Czasopismo Zakładu Narodowego im. Ossolińskich, z. 1, 1992, 144, przyp. 11.

5 Zob. Maciej Matwijów, Zakład Narodowy imienia Ossolińskich w latach 1939-1946 (Wrocław: Towarzystwo Przyjaciół Ossolineum, 2003), 81. 
przekazanych Bibliotece Ossolineum”; d) „IV. Listy”. Opatrzone są one wspólnym tytułem: „Spis materiałów rękopiśmiennych, manuskryptów niepublikowanych oraz listy uczonych polskich i zagranicznych pisanych do Ingardena w latach 1915-1940, przekazanych Bibliotece Ossolineum we Lwowie w 1940 roku". Warto podkreślić datę pierwszego przekazania archiwaliów. Doszło do tego 15 kwietnia 1940 roku, a więc tuż po akcji deportacyjnej, która miała miejsce w nocy z 12 na 13 kwietnia zarówno we Lwowie, jak i na całym obszarze ziem Rzeczpospolitej Polskiej, okupowanym przez Związek Radziecki. Akcja ta sterroryzowała całe miasto, ciągnęła się gdzieniegdzie jeszcze $13 \mathrm{kwietnia,} \mathrm{a} \mathrm{pocią-}$ gi załadowane ponad siedmioma tysiącami dorosłych, starców i dzieci stały na lwowskich stacjach jeszcze 14 kwietnia $^{6}$. Ingarden wiedział, że komuniści nie będą mieli wobec niego żadnych skrupułów. Cztery miesiące wcześniej, w grudniu 1939 roku, funkcjonariusze NKWD aresztowali jego syna Jerzego, oskarżając go o działalność w tajnym związku Polska Organizacja Partyzancka ${ }^{7}$, po czym wywieziono go ze Lwowa w nieznanym kierunku. Rodzice nie wiedzieli nawet, czy jeszcze żyje. Fenomenolog spodziewał się, że chociażby z powodu syna był dla organów bezpieczeństwa osobą podejrzaną. I słusznie, gdyż uznano go w raporcie NKWD za „przedstawiciela tej części polskiej inteligencji, która jest jawnie wroga wobec Sowwłasti i Armii Czerwonej"8. Ingarden obawiał się, że do jego domu wkroczą funkcjonariusze NKWD, wyznaczą trzydzieści minut na spakowanie się, a następnie wywiozą w bydlęcych wagonach na Wschód, w kierunku nieznanej lokalizacji. Wiedział, że w takiej sytuacji nie będzie miał możliwości zabezpieczyć losów cennych rękopisów. Dlatego też zawczasu zdecydował się przygotować na najgorsze. Nie spodziewał się, że on sam z żoną bezpiecznie przeżyją okres pierwszej okupacji lwowskiej, a inny los będzie czekał jego siostrę Jadwigę, która dwa i pół miesiąca później, podczas akcji deportacyjnej bieżeńców, zostanie wywieziona do Joszkar-Oła w Maryjskiej ASRR?.

${ }^{6}$ Zob. Grzegorz Hryciuk, Polacy we Lwowie 1939-1944. Życie codzienne (Warszawa: Książka i Wiedza 2000), 39-40.

7 Zob. list Iwana A. Sierowa, Ludowego Komisarza Spraw Wewnętrznych Ukraińskiej Socjalistycznej Republiki Radzieckiej do Ławrentina P. Berii, Ludowego Komisarza Spraw Wewnętrznych Związku Socjalistycznych Republik Radzieckich, [brak lokalizacji miejsca], marzec 1940 r. [brak daty dziennej], w: Polska $i$ Ukraina w latach trzydziestych-czterdziestych XX wieku. Nieznane dokumenty z archiwów służb specjalnych. Polskie podziemie 1939-1941, red. Zuzanna Gajowniczek i in., t. 1: Lwów-Kołomyja-Stryj-Złoczów (Warszawa-Kijów 1998), 45-51.

8 Tamże, 47.

9 Datacja aresztowania Jadwigi Ingardenówny jest podana w liście Romana Witolda Ingardena do Stefana Szumana z 14 września 1941 roku (zob. Marek M. Tytko, „Mjr prof. Stefan Szuman w walce o niepodległość Polski (1939-1945)”, Sowiniec 44 (2014), 66. 
Ingarden wiedział, że jego najcenniejsze zbiory, choć nie całkowicie bezpieczne, będą miały większą szansę przetrwania trudnego okresu pod opieką Stefana Inglota niż w jego własnym mieszkaniu. Z chwilą przekazania depozytu opustoszał lwowski gabinet filozofa. Stało się jasne, że dalsza praca naukowa będzie przebiegać w trudnych warunkach. Zresztą w latach wojny we Lwowie Ingarden miał też dużo innych zmartwień. Zatroskany był przede wszystkim losem swojego syna Jerzego, który wraz z armią Andersa ruszył na nieznany szlak bojowy i z którym przez długie miesiące nie było kontaktu. Troszczył się także o zdrowie ukochanej siostry Jadwigi, która jako bieżeniec została wywieziona do Maryjskiej ASRR, a później opiekowała się dziećmi w sierocińcu przy armii Andersa, by ostatecznie osiedlić się w Meksyku. Nie był mu obcy także los kolegów filozofów. Nigdy nie wspominał o tym publicznie, lecz przeżywał każdą śmierć, każde aresztowanie. Najbardziej bolał go brak jakichkolwiek wiadomości o Edith Stein. Niemoc panująca we Lwowie była nie do zniesienia. Ingarden pracował w tym czasie głównie nad rękopisem I tomu Sporu o istnienie świata. Gdy zaś w 1943 roku nadeszła informacja o możliwości zatrudnienia żony Nuny na etacie lekarskim w sierocińcu w Pieskowej Skale pod Krakowem, nie wahał się ani chwili i pośpiesznie opuścił Lwów. Zdecydował się na ten krok w obliczu nadciągającej ofensywy wojsk radzieckich, a także w związku z faktem, że jego mieszkanie ucierpiało na skutek bombardowania. Stało się wówczas oczywiste, że drugiej okupacji radzieckiej Ingarden we Lwowie nie przeżyje.

Pobyt w Pieskowej Skale i okres wyzwolenia wiązał się w życiu Ingardena z kolejnymi wyborami. Filozof nie zabiegał w tym czasie o zatrudnienie w żadnym z polskich uniwersytetów. Najbliższy geograficznie, choć nie mentalnie, był mu Uniwersytet Jagielloński. Ostatecznie po przetoczeniu się frontu, nakłoniony przez dziekana Zawirskiego, fenomenolog zdecydował się na podjęcie zajęć z filozofii na tej uczelni. Po wojnie aktywnie włączył się w życie naukowe, jednocześnie martwiąc się o pozostawione we Lwowie materiały archiwalne oraz księgozbiór $^{10}$. Jeszcze w 1945 roku podjął konkretne działania instytucjonalne związane z procesem rewindykacyjnym. W ramach wznawiającej działalność Polskiej Akademii Umiejętności ${ }^{11}$ niemal od razu zrodziła się

${ }_{10}$ Niniejszy fragment pokrywa się z naszymi rozważaniami zawartymi w pracy: Radosław Kuliniak, Mariusz Pandura, Łukasz Ratajczak, Filozofia po ciemnej stronie mocy. Krucjaty marksistów i komunistów polskich przeciwko Lwowskiej Szkole Filozoficznej Kazimierza Twardowskiego. Cz. I: Lata 1945-1951 (Kęty: Wydawnictwo Marek Derewiecki, 2018), 37-43.

${ }^{11}$ Zob. Piotr Hübner, Siła przeciw rozumowi... Losy Polskiej Akademii Umiejętności w latach 1939-1989 (Kraków: Secesja, 1994), 12-31. 
idea rewindykacji dóbr kulturalnych polskich we Lwowie ${ }^{12}$. 31 sierpnia 1945 roku odbyło się niejawne spotkanie sygnatariuszy akcji rewindykacyjnej w sprawie polskich, lwowskich dóbr kulturalnych. Wieść o nim rozeszła się po Krakowie w mgnieniu oka. Dotarła również do Ingardena, który był zdziwiony, że nie otrzymał zaproszenia. Czuł się pominięty, a nawet, jako jeden z opiekunów dóbr filozoficznych będących spuścizną po Twardowskim i Polskim Towarzystwie Filozoficznym oraz jako przewodniczący Komitetu Wydawniczego Pism Twardowskiego, był tym faktem oburzony. Tego samego dnia wystosował pismo do Sekretarza Generalnego Polskiej Akademii Umiejętności, profesora Tadeusza Kowalskiego ${ }^{13}$. Znajduje się w nim spis rzeczy, które filozofia polska zostawiła w depozycie i utraciła we Lwowie. Ingarden pisał:

Jakkolwiek nie zostałem zaproszony na dzisiejsze posiedzenie w sprawie rewindykacji dóbr kulturalnych polskich we Lwowie, organizowane przez PAU, dowiedziawszy się o nim prywatnie, poczuwam się do obowiązku zwrócenia uwagi Szanownych Panów na następujące sprawy, które nie mogą być pominięte przy ustalaniu naszych postulatów rewindykacyjnych: 1. Polskie Towarzystwo Filozoficzne we Lwowie złożyło do depozytu jeszcze w 1938 roku w Bibliotece Uniwersyteckiej we Lwowie cała rękopiśmienniczą spuściznę po prof. K. Twardowskim, członku

12 Wśród podjętych przez Polską Akademię Umiejętności działań trzeba wskazać: Protokół posiedzenia Komitetu PAU, 31 VIII 1945 (brulion), Archiwum Nauki PAN i PAU, KSG PAU 481/1945. Pod tym numerem znajduje się protokół Komitetu dla przygotowania materiału dla Ministerstwa Oświaty w sprawie rewindykacji dóbr kulturalnych z utraconych ziem wschodnich, odbytego 28 IX 1945, w którym uczestniczył Ingarden (podpisany na liście obecności). Pod tym numerem znajduje się też pismo i tekst Ingardena z 31 VIII 1945 oraz teksty innych autorów dotyczące poszczególnych zbiorów. Bardzo dziękujemy Pani Dr Ricie Majkowskiej za powyższą informację. Spośród innych ważnych dokumentów dotyczących tej kwestii należy wymienić: Projekt memoriału Polskiej Akademii Umiejętności „W sprawie obrony zbiorów Ossolineum we Lwowie i innych zabytków kulturalnych polskich na wschodzie". [Kraków po 10 października 1945]; Uchwałę Rady Komisarzy Ludowych Ukraińskiej SRR nr 1673 w sprawie przekazania Tymczasowemu Rządowi Jedności Narodowej RP polskiego mienia kulturalnego, Kijów 18 października 1945; Memoriał Polskiej Akademii Umiejętności do prezydenta Krajowej Rady Narodowej Bolesława Bieruta „W sprawie repatriacji archiwów, bibliotek oraz muzeów naukowo-artystycznych ze Lwowa i Wilna”, Kraków [przed 19 października 1945]. Materiały dołączone są do pracy: Matwijów, Walka o lwowskie dobra kultury w latach 1945-1948, Część II: „Wybór dokumentów” (Wrocław: Towarzystwo Przyjaciół Ossolineum, 1996), 159-308.

${ }_{13}$ Zob. brudnopis pisma Romana Witolda Ingardena do Sekretarza Polskiej Akademii Umiejętności Tadeusza Kowalskiego z 31 sierpnia 1945 roku, w: „ARI”. Oryginał pisma (znak PTF 11/45) na papierze firmowym z datą 31 VIII 1945 roku, podpisanego przez Ingardena wraz z jego tekstem „Polskie Towarzystwo Filozoficzne" znajduje się w Archiwum Nauki Polskiej Akademii Nauk i Polskiej Akademii Umiejętności pod sygnaturą PAU KSG 481/1945. Bardzo dziękujemy Pani Dr Ricie Majkowskiej za tę informację. 
PAU, a to 1. Prace filozoficzne niepublikowane, 2. Wykłady uniwersyteckie z lat 30., nadto 3. listy prof. Twardowskiego. Papiery te stanowią własność Polskiego Towarzystwa Filozoficznego na podstawie aktu darowizny rodziny śp. Prof. Twardowskiego. Złożono je w Bibliotece jedynie dla lepszego zabezpieczenia. Polskie Towarzystwo Filozoficzne przystąpiło jeszcze w roku 1938 do opracowania materiału rękopiśmiennego prof. Twardowskiego celem przygotowania do druku pism pośmiertnych. 2. Biblioteka osobista prof. Twardowskiego została złożona przez prof. Ajdukiewicza w Ossolineum i tam się powinna znajdować. 3. W grudniu roku 1939 Polskie Towarzystwo Filozoficzne złożyło jako depozyt w Bibliotece Uniwersyteckiej bibliotekę Towarzystwa wraz z szafami, $\mathrm{w}$ tym kilkadziesiąt czasopism filozoficznych zagranicznych $\mathrm{z}$ lat ostatnich przed wojna, stanowiących własność czasopisma Studia Philosophica, egzemplarzy wymiennych, których zresztą w Polsce nie ma, bo jedynie Polskie Towarzystwo Filozoficzne utrzymywało stosunki z zagranicznym ruchem filozoficznym. 4. W jesieni roku 1939 złożyła redakcja $R u$ chu Filozoficznego (czasopisma wydawanego przez Polskie Towarzystwo Filozoficzne) swoje materiały redakcyjne z okresu 30-letniego istnienia czasopisma jako depozyt w Bibliotece Uniwersyteckiej we Lwowie. 5. W lipcu roku 1943 redakcja czasopisma Studia Philosophica. Commentarii Societatis Philosophicae Polonorum złożyła jako depozyt w Lwowskiej Bibliotece Uniwersyteckiej materiały redakcyjne, w tym szereg prac złożonych w redakcji do druku w III tomie, którego częściowy skład, około 10 arkuszy druku, został zniszczony przez władze okupacyjne. Bez tych prac, częściowo nie żyjących już dziś autorów, redakcja nie może zrekonstruować III tomu. O wszystkich tych depozytach mających częściowo podstawowe znaczenie dla dziejów polskiej filozofii w $\mathrm{XX}$ wieku do wybuchu wojny jest poinformowany kustosz Biblioteki Uniwersyteckiej dr Franciszek Smolka, zarazem bibliotekarz Polskiego Towarzystwa Filozoficznego, który depozyty te przejmował w imieniu Biblioteki Uniwersyteckiej. 6. W Muzeum Narodowym Ukraińskim we Lwowie zostały złożone podczas okupacji niemieckiej przez prof. K. Ajdukiewicza różne papiery i pamiątki po śp. Prof. K. Twardowskim jako depozyt stanowiący własność Polskiego Towarzystwa Filozoficznego. Nadto Polskie Towarzystwo Filozoficzne poniosło wskutek okupacji Lwowa przez wojska obce następujące straty, które powinny zostać w jakiś sposób wyrównane: 1) magazyn wydawnictw własnych, złożony w lokalu Seminarium Filozoficznego Uniwersytetu Jana Kazimierza, a zabrany przez sowieckie władze uniwersyteckie na wiosnę roku 1940 do jakiegoś innego lokalu w głównym (nowym) gmachu Uniwersytetu, gdzie po tym ślad za nim zaginął. Wydawnictwa te miały przed wojną wartość około 10,000 złotych przedwojennych. 2) wydawnictwa własne Polskiego Towarzystwa Filozoficznego złożone na skład księgarni Mazuccato-y (w tym zapas egzemplarzy dwóch roczników Studia Philosophica i Biblioteczki Filozoficznej) wartości około 20,000 złotych przedwojennych. Wydawnictwa te zostały albo zniszczone w czasie okupacji w latach 1939-41, albo też zabrane przez ukrainców [sic!] w roku 1941 za okupacji niemieckiej. Polskie Towarzystwo Filozoficzne złożyło w lipcu roku 1941 na ręce zarządu ukraińskiego wymienionej księgarni (i Książnicy-Atlas) swoją pretensję 
do własności wymienionych wydawnictw. Pismo Polskiego Towarzystwa Filozoficznego w tej sprawie pozostało bez odpowiedzi. 3) papier do III tomu Studia Philosophica, złożony w lwowskiej Drukarni Związkowej przy ul. Lindego, wartości około 600 złotych, który władze okupacyjne zużyły na własne cele. Prócz tego pozwalam sobie zwrócić uwagę, że Biblioteka Seminarium Filozoficznego Uniwersytetu Jana Kazimierza, rozproszona przez sowieckie władze uniwersyteckie w latach 1939-41, została w lutym roku 1943 (w znalezionej wówczas części) przewieziona przez niżej podpisanego i przez prof. Ajdukiewicza do Ossolineum, skąd jeszcze w sierpniu roku 1943 została zabrana do Biblioteki Pedagogicznej przy ul. Kubali przez ówczesnego dyrektora tejże Biblioteki dr Kuchtę (Ukraińca). Inna część biblioteki Seminarium Filozoficznego została złożona w Bibliotece Uniwersyteckiej. Za czasów okupacji niemieckiej widziano książki Seminarium Filozoficznego wśród zbiorów Ukraińskiego Towarzystwa Naukowego im. Szewczenki we Lwowie. Pozwalam sobie zaznaczyć, że od roku 1895 we Lwowie koncentrował się główny ruch filozoficzny i że odzyskanie choćby drobnej części polskiego dorobku $\mathrm{w}$ dziedzinie filozofii $\mathrm{z}$ okresu ostatnich lat 50 ma zasadnicze znaczenie dla możliwości kiedyś historii filozofii polskiej. Prócz tego materiały, na które wskazuję, są także potrzebne dla wielu prac dzisiejszych w pozytywnych badaniach filozoficznych w Polsce. Odpowiednio dobierana przez 50 lat biblioteka Seminarium Filozoficznego także stanowi instrument pracy w zakresie filozofii, jakiego żaden inny uniwersytet w Polsce nie posiada. Uratowanie tego instrumentu miałoby podstawowe znaczenie dla dalszych badań w zakresie filozofii. Prosząc uprzejmie Wielce Szanownego Pana Profesora o przedłożenie wszystkich tych spraw dzisiejszemu posiedzeniu, łączę wyrazy głębokiego poważania i szacunku, Redaktor czasopisma Studia Philosophica, Wiceprezes Polskiego Towarzystwa Filozoficznego we Lwowie ${ }^{14}$.

Ingarden podjął także starania, aby przy pomocy przebywającego we Lwowie Romana Stanisława odzyskać i przetransportować stamtąd części pozostawionego majątku rodzinnego, w tym także księgozbioru, maszynopisów i rękopisów.

W liście z 7 lutego 1945 roku fenomenolog wydał synowi dyspozycje dotyczące tego, jakie rzeczy należy przewieźć ze Lwowa do Krakowa:

Chwała Bogu, że jesteś zdrów. Cieszę się też, że nasze mieszkanie ocalało, że mogłeś choć część mebli dla Siebie użyć, resp. sprzedać. Szkoda, że cokolwiek tam zostało. Gdy będziesz wyjeżdżał, na co wszyscy bardzo czekamy (tu jest Twój dawny profesor), postaraj się zabrać wszystkie książki naukowe, a z literatury pięknej przede wszystkim wydania pisarzy. Najlepiej byłoby zabrać wszystkie książki, ale zależy od tego, czy nie będą za ciężkie. M.in. są jeszcze moje prace, które muszę zabrać. Prócz tego nuty. Prócz książek, żebyś zabrał koniecznie wszystkie moje manu-

${ }^{14}$ Zob. tamże. 
skrypty. Kustosz M. powie Ci, gdzie leżą (trzy paczki!), nadto listy Husserla (oryginały!), włożone między książki moje. Listy uczonych polskich i zagranicznych także! W bibliotece znajdują się wreszcie nasze obrazy: a) portrety Witkacego, b) cztery portrety Władka Radwańskiego, dziadka Ingardena, mój i Janka, c) rysunki Janka. Trzeba to koniecznie wszystko zabrać. Byłoby także dobrze zabrać garnki do gotowania, o ile możesz to jeszcze wziąć. Co do mebli, to albo je sprzedasz, albo komu z naszych znajomych odstąpisz, o ile kto z naszych znajomych by tam zostawał. [...] Nie zapomnij zabrać z Biblioteki naszej Matki Boskiej Rafaela (kopia) i medalionów, zwłaszcza Słowackiego. Z domu zabierz, o ile można, pamiątki po stryju i dziadku, ramy, o ile za ciężkie, sprzedaj. W pierwszej są różne rzeczy, nie zapomnij. W mym biurku i w bibliotece były jeszcze jakieś papiery moje. Co warto zabrać, zabierz. U Baworowskich jest nasza szafka na książki, albo tam zostaw, albo u kogoś, kto potrafi zachować15.

Powyższy list trafił do Lwowa dwa i pół tygodnia później, około 25 lutego. Roman Stanisław podjął energiczne działania mające na celu odzyskanie dóbr rodzinnych i przygotowanie ich do transportu. Udało mu się zabrać książki ojca, a także zorganizować transport z Optyczno-Mechanicznych Zakładów "Jan Bujak”, w których pracował. Relację ze swoich poczynań przedstawił ojcu w liście z 16 marca:

Nie mogłem wcześniej wysłać odpowiedzi, bo nie było żadnej okazji przesłania jej, tzn. żadne samochody z firmy nie jechały do Krakowa. Obecnie wyjeżdża samochód. Gdyby nie to, że wyjazd ten został dopiero wczoraj zadecydowany, może mógłbym nim sam pojechać do Krakowa. Ale nie byłem przygotowany do wyjazdu i nie miałem wszystkich rzeczy spakowanych. To, co miałem spakowane, mianowicie cztery skrzynie książek, które wyciągnąłem od Baworowskich, wysyłam tym samochodem. Okazało się w Bibliotece, że zasadniczo jest wszystko, to, co pisałem, polegało na nieporozumieniu, mianowicie dawniej nie pokazano mi jeszcze jednej i to największej szafy z książkami. Wszystkie książki przesortowałem, zostawiłem dosyć sporo książek mniej ważnych i mniej wartościowych, powieści, większość różnych odbitek i różne inne śmiecie. Jeśli chodzi o czasopisma, to zostawiłem Kant-Studien i Slavische Rundschau, a inne, a mianowicie Przeglą Filozoficzny, Ruch Filozoficzny i księgi zjazdów: praskiego filozoficznego, paryskiego filozoficznego i paryskiego estetycznego odłożyłem i wezmę, jeśli będę miał jeszcze miejsce. Proszę mnie koniecznie napisać, czy te czasopisma trzeba brać, czy nie. Zasadniczo co do biblioteki Tatusia i Mamusi (medyczna), którą wysegregowałem do zabrania (z wyjątkiem niedużej ilości książek filozoficznych, które mam jeszcze w domu niezapakowane, m.in. Windelband, Überweg, Tatarkiewicz Historia Filozofii drugi tom - pierwszego brakuje - i kilku innych), jest w czterech skrzyniach, które wysyłam. Jeśli Tatuś nie znajdzie cze-

15 Zob. list Romana Witolda Ingardena do Romana Stanisława Ingardena, Kraków, 7 lutego 1945 roku, w: ARI. 
goś potrzebnego, to proszę mnie koniecznie napisać i ja wezmę z resztą książek. Tę resztę tworzą przede wszystkim moje książki, które zastałem w domu. Będzie tego na dwie skrzynie, takiej wielkości jak te, które wysyłam, albo 3-4 mniejsze (zdaje się, że będę miał mniejsze skrzynie). Bardzo się cieszę, że udało mi się posłać skrzynie samochodem, bo odpada trudna sprawa transportu w Krakowie z dworca do domu, a skrzynie są bardzo ciężkie. Myślę, że skrzynie te chyba dojdą do Krakowa w porządku. Ponieważ nie znam nowego adresu Tatusia, podaję szoferowi adres na Wrzesińskiej, można będzie jednak na miejscu samochód skierować pod nowy adres i przez to odpadnie trudność przenoszenia. Prócz książek w skrzyni nr 4 znajdują się 2 paczki papierów, zdaje się, że listy uczonych polskich i Husserla i figurka Asnyka. Proszę potwierdzić odbiór szoferowi i sprawdzić, czy wszystko w porządku. Skrzynie są opakowane napisami po rosyjski, bo z samochodem jadą wojskowi i ponumerowane 1-4. Od Baworowskich wyciągnąłem też wszystkie obrazy i papiery (także medaliony). Jeśli chodzi o szafkę biblioteczną, to wziąć się jej nie da, jak w ogóle żadnych mebli. Jest to dosyć nieprzyjemne, bo Tatuś tam nie ma pewnie zupełnie żadnych mebli i spodziewa się, że ja przywiozę. Do transportu kolejowego mebli „pod żadną postacią” brać nie wolno. Ja staram się więc meble tutaj sprzedać, ale to sprawa trudna. Na razie nic nie sprzedałem $\mathrm{z}$ wyjątkiem tego, co sprzedałem jeszcze w sierpniu [...]. Może uda się mi wziąć niektóre meble (ale nie wszystkie), gdybym pojechał nie koleja, ale samochodem. [...] Wczoraj byłem na Pawlikowskiego w naszym dawnym mieszkaniu. [...] Nasze mieszkanie jest zamknięte na wielkie kłódki, okna zabite dyktą i zajęte w ten sposób przez pewnego Rosjanina z fabryki rowerów. On przychodzi tu przez pewien czas, ale nie mieszka jeszcze, ma dopiero zamieszkać podobno w kwietniu, jak sprowadzi sobie żonę z Rosji. W mieszkaniu jest część naszych mebli, m.in. dwa kredensy, stół jadalny, szafa na ubrania Dziadka, stół kuchenny, biała szafa, kanapa, trochę krzeseł i skrzynia w kuchni. Do skrzyni tej złożyłem rzeczy, które znajdowały się w bibliotece, i w szafie na moje książki (u dołu), i w szafie na korytarzu. Są to czasopisma medyczne Mamusi i różne papiery, fotografie, rękopisy itd. Dziadka. Ja wybrałem z tego tylko drukowane prace Dziadka, które biorę. Co zrobić z resztą? Czy opłaca się to brać? Część rzeczy Dziadka, a mianowicie plany i zdjęcia wodociagón krakowskich i jakieś różne techniczne opisy i kosztorysy, są w Bibliotece Baworowskich. Ja to tam zostawiłem, ale jeśli Tatko uważa, że należy zabrać, to zabiorę. Proszę mnie napisać dokładnie. Nowy lokator mieszkania wszystko mi wyda i powiedział też, że kupi rzeczy, ale dawno z nim się nie widziałem. [...] firma [Bujak] robi mi tyle grzeczności (dali mi skrzynie, przewożą rzeczy samochodem i może sam pojadę firmowym wozem). [...] Muszę już kończyć, bo samochód już odjeżdża ${ }^{16}$.

16 Zob. list Romana Stanisława Ingardena do Romana Witolda Ingardena, Lwów, 16 marca 1945 roku, w: ARI. 
Tak więc partia zbiorów Ingardena została wywieziona ze Lwowa do Krakowa już 16 marca 1945 roku. Z ustaleń Macieja Matwijowa wiemy jednak, że doszło do jeszcze jednego transportu. Kolejnę część biblioteki Ingardena przewieziono ze Lwowa na zachód pod koniec kwietnia. Było to możliwe dzięki energicznej postawie Ignacego Szaniawskiego (Sznajera), członka Komisji Opieki nad Książką Związku Patriotów Polskich. Partię księgozbioru Ingardena dostarczono samochodami wraz ze zbiorami Bohdana Suchodolskiego oraz Jana Czekanowskiego w transporcie liczącym w sumie około 10 tysięcy książek. Stało się to pomimo ogromnych ograniczeń finansowych osób pracujących nad tym przedsięwzięciem ${ }^{17}$.

W sprawie pozostałej części własnego księgozbioru, pozostawionej we Lwowie, Ingarden pisał nieco później, 6 lutego 1951 roku, do dyrektora Biblioteki Uniwersyteckiej we Wrocławiu, dra Antoniego Knota $^{18}$. Żywił wówczas cały czas nadzieję na odzyskanie cennych materiałów naukowych pozostawionych we Lwowie. W liście informował Bibliotekę Uniwersytecką o swoim księgozbiorze rzekomo wchodzącym w zasoby Biblioteki Baworowskich, a dodatkowo o złożonych w depozycie w Bibliotece Uniwersyteckiej we Lwowie pracach Twardowskiego. Były to informacje już wcześniej przekazane przez Ingardena w liście do Sekretarza Generalnego Polskiej Akademii Umiejętności Jerzego Kowalskiego. Po odzyskaniu dalszej części swojego księgozbioru ze Lwowa Ingarden chciał go złożyć w depozycie we Wrocławiu. W liście zwrotnym do Ingardena z Biblioteki Uniwersyteckiej, podpisanym przez dra Knota, czytamy:

Wielce Szanowny Panie Profesorze,

Dzisiaj dopiero odpowiadamy na list Pana z dnia 6 II bieżącego roku, który otrzymaliśmy z opóźnieniem, już po otrzymaniu kilku cennych prac Pańskich. Dziękujemy uprzejmie za informacje w sprawie książek Pana Profesora w Bibliotece Baworowskich i depozytu prac śp. Prof. Dr K. Twardowskiego w b. Bibliotece Uniwersyteckiej we Lwowie - oraz gotowość ofiarowania nam swego księgozbioru w razie odzyskania go ze Lwowa. Sprawa ta jednak wymaga uprzedniego przygotowania w porozumieniu z Ministerstwem Szkół Wyższych i Nauki, ponieważ dotyczy zbiorów położonych za granicą. Dyrekcja Biblioteki dołoży wszelkich starań celem sprowadzenia tak cennych depozytów do Wrocławia. Po zasięgnięciu informacji u władz naczelnych pozwo-

17 Zob. Matwijów, Walka o lwowskie dobra kultury w latach 1945-1948, 134.

18 Z tego czasu pochodzą dwa listy: Romana Witolda Ingardena do Biblioteki Uniwersyteckiej we Wrocławiu z 6 lutego 1951 roku i odpowiedź Dyrektora Biblioteki Uniwersyteckiej we Wrocławiu dra Antoniego Knota z 20 lutego 1951 roku, w: ARI. 
limy sobie zwrócić się do Pana Profesora o formalne pełnomocnictwo i zaświadczenia.

Łączymy wyrazy głębokiego poważania. Dr Antoni Knot, Dyrektor Biblioteki ${ }^{19}$.

Głos Ingardena w sprawie rewindykacji lwowskich archiwaliów filozoficznych był pionierski. Ingarden jako pierwszy upomniał się otwarcie o zwrot pozostawionych we Lwowie dóbr filozoficznych. Był to jednak głos osamotniony. Ani bowiem Ajdukiewicz, ani inni filozofowie polscy powracający ze Lwowa po wojnie nie tylko nie zdołali przywieźć do kraju ocalałych tam dokumentów archiwalnych, ale również nie mieli większego wpływu na ich odzyskanie.

Ostatnie spisy manuskryptów piśmienniczych Ingardena powstały trzy lata przed śmiercią filozofa. Być może przeczuwał on wówczas nadchodzący koniec życia i dlatego podjął się ostatecznej inwentaryzacji zasobów archiwalnych. Początkowo Ingarden nad swoim zbiorem pracował sam. Uczynił własnoręczny spis, którego jednak nie dokończył, zatrzymał się bowiem na numerze 61 pkt. 1. Wiemy również, że Ingarden ponownie spisał całość na maszynie. Niestety jak dotąd nie znaleźliśmy tego spisu. Wiemy jednak, że gdy filozofowi coraz bardziej ubywało sił, do inwentaryzacji włączyła się jego ulubiona uczennica, a mianowicie Danuta Gierulanka. To ona przepisała z maszynopisu Ingardena przygotowany przez niego spis i go dopełniła. Prace nad nim trwały dość długo, a zostały ukończone po śmierci filozofa. Na dokonanym przez Gierulankę spisie widnieje zapis: „ZZ maszynopisu Autora (do 79 włącznie) przepisała D. Gierulanka, 11 X 1970 r.".

Nie był to oczywiście koniec prac związanych ze materiałami filozofa. Niedługo po śmierci fenomenologa Nuna podzieliła je pomiędzy synów. Powstał wówczas pomysł przekazywania partiami tych archiwaliów rodzinnych do jednej z bibliotek krakowskich. Manuskrypty rodzina postanowiła złożyć w Oddziale Archiwum Polskiej Akademii Nauk w Krakowie, a jej pośredniczką w rozmowach i opiekunką zbiorów została Gierulanka. Do rozmów wstępnych doszło jeszcze w październiku 1970 roku $^{20}$. Ustalono, że najpierw zostaną przekazane manuskrypty prac i inne dokumenty rękopiśmienne z wyłączeniem materiałów oraz pamiątek rodzinnych. Był to dar rodziny Ingardenów, który ofiarowano przede wszystkim z myślą o kontynuowaniu prac edytorskich nad rękopisami filozofa. Jednym z warunków postawionych przez

19 Zob. list dra Antoniego Knota, Dyrektora Biblioteki Uniwersyteckiej we Wrocławiu, do Romana Witolda Ingardena z 10 lutego 1946 roku, w: ARI.

${ }^{20}$ Polską Akademię Nauk reprezentował kierownik Oddziału Archiwum PAN w Krakowie, mgr Jan Poradzisz. Bardzo dziękujemy Pani Dr Ricie Majkowskiej za tę informację. 
spadkobierców było przygotowanie mikrofilmów z przekazanego daru, na co stosowną zgodę wydała centrala warszawska. Była to jedna z właściwych decyzji dyrektora Archiwum PAN w Warszawie, Zygmunta Kolankowskiego ${ }^{21}$.

W 1972 roku Janusz Ingarden przekazał do Oddziału Archiwum Polskiej Akademii Nauk w Krakowie pierwszą część spuścizny ${ }^{22}$. Druga część przez wiele lat pozostawała w Toruniu w rękach Romana Stanisława Ingardena ${ }^{23}$. Niektóre jej partie także przekazywano do Archiwum. W 1984 roku obaj synowie Ingardena zastrzegli sobie pełnię praw autorskich do tych materiałów i upoważnili do dalszej opieki nad nimi Danutę Gierulankę. W 2002 roku przekazywany sukcesywnie do Oddziału Archiwum Polskiej Akademii Nauk w Krakowie zasób archiwaliów Ingardena wszedł do zbiorów nowo utworzonego Archiwum Nauki PAN i PAU w Krakowie. Z kolei po śmierci Romana Stanisława w 2011 roku toruńską część zbiorów przejął jego syn Krzysztof Ingarden i przeniósł do Krakowa. W efekcie całość spuścizny Ingardena ponownie znalazła się w tym mieście. W 2016 roku doszło do przekazania w depozyt kolejnej część materiałów do Archiwum Nauki PAN i PAU w Krakowie.

Dalsze losy materiałów archiwalnych oraz biblioteki są kształtowane przez Krzysztofa Ingardena i archiwistów z Archiwum Nauki PAN i PAU w Krakowie. Od prawie dwudziestu lat trwa akcja przekazywania spuścizny filozofa do wspomnianego archiwum. Jest to proces, który wymaga od obu stron ogromnego zaangażowania oraz rozważnych i dobrze udokumentowanych działań. Spuścizny po Ingardenie należy strzec przed niepożądanymi działaniami, jako naszego dobra narodowego. Każda bowiem zła ingerencja $w$ to niewątpliwe dobro przyczyni się do jego niechybnego rozpadu.

\section{Bibliografia}

Brudnopis pisma Romana Witolda Ingardena do Sekretarza Polskiej Akademii Umiejętności Tadeusza Kowalskiego z 31 sierpnia 1945 roku. W: ARI. Oryginał pisma (znak PTF 11/45) na papierze firmowym $z$ datą 31 VIII 1945 roku, podpisanego przez Ingardena wraz z jego tekstem

${ }^{21}$ O podwójnym obliczu Kolankowskiego zob. Alicja Kulecka, Tadeusz P. Rutkowski, Oczami agenta. Środowiska naukowe i archiwalne w doniesieniach TW "Zyg" Zygmunta Kolankowskiego (Warszawa: Wydawnictwo Neriton, 2012).

${ }_{22}$ Materiały były przekazywane partiami w związku z prowadzonymi równocześnie pracami edytorskimi. Za tę informację Pani Dr Rita Majowska będzie łaskawa przyjąć nasze ogromne podziękowania.

${ }^{23}$ Roman Stanisław Ingarden przechowywał materiały rodzinne oraz korespondencję. Informacja ta pochodzi od Pani Dr Rity Majkowskiej, której bardzo dziękujemy. 
„Polskie Towarzystwo Filozoficzne” znajduje się w Archiwum Nauki Polskiej Akademii Nauk i Polskiej Akademii Umiejętności pod sygnaturą PAU KSG 481/1945.

Dwa listy: Romana Witolda Ingardena do Biblioteki Uniwersyteckiej we Wrocławiu z 6 lutego 1951 roku i odpowiedź Dyrektora Biblioteki Uniwersyteckiej we Wrocławiu dra Antoniego Knota z 20 lutego 1951 roku. W: ARI.

Hryciuk Grzegorz. 2000. Polacy we Lwowie 1939-1944. Życie codzienne. Warszawa.

Hübner Piotr. 1994. Sita przeciw rozumowi..., Losy Polskiej Akademii Umiejętności w latach 1939-1989, „Rozdział drugi: Na starych fundamentach... (1945)", Kraków: Secesja, 12-31.

Inglot Stefan. Brudnopis „Sprawozdania z czynności pracowników Oddziału Rękopisów filii Biblioteki Akademii Nauk USRR przy ulicy Ossolińskich 2 za miesiąc kwiecień [1940 roku]", Аьвівська національна наукова бібліотека України імені В.Стефаника. Відділ рукописів, ф. 54, оп. 2, од. зб. 84, 374.

Inglot Stefan. Brudnopis „Sprawozdania z pracy [Oddziału Rękopisów] w miesiącu styczniu 1940 [roku]", Дьвівська національна наукова бібліотека України імені В.Стефаника ім. В. Стефаника. Відділ рукописів, $ф .54$, оп. 2, од. зб. 84, s. 54.

Jabłoński Zbigniew. „Sprawozdanie z działalności Biblioteki Polskiej Akademii Nauk w Krakowie za okres od 1 I-31 XII 1970", Rocznik Biblioteki Polskiej Akademii Nauk w Krakowie, R. 16, 1970, wyd. 1971, 275-289.

Kulecka Alicja, Tadeusz P. Rutkowski. 2012. Oczami agenta. Środowiska naukowe $i$ archiwalne $w$ doniesieniach TW "Zyg" - Zygmunta Kolankowskiego. Warszawa: Wydawnictwo Neriton.

Kuliniak Radosław, Mariusz Pandura, Łukasz Ratajczak. 2018. Filozofia po ciemnej stronie mocy. Krucjaty marksistów i komunistów polskich przeciwko Lwowskiej Szkole Filozoficznej Kazimierza Twardowskiego. Cz. I: Lata 1945-1951. Kęty: Wydawnictwo Marek Derewiecki.

List Dra Antoniego Knota, Dyrektora Biblioteki Uniwersyteckiej we Wrocławiu, do Romana Witolda Ingardena z 10 lutego 1946 roku. W: ARI.

List Iwana A. Sierowa, Ludowego Komisarza Spraw Wewnętrznych Ukraińskiej Socjalistycznej Republiki Radzieckiej do Ławrentina P. Berii, Ludowego Komisarza Spraw Wewnętrznych Związku Socjalistycznych Republik Radzieckich, [brak lokalizacji miejsca], marzec 1940 r. [brak daty dziennej]. W: Polska i Ukraina w latach trzydziestych-czterdziestych XX wieku. Nieznane dokumenty z archiwów stużb specjalnych. Polskie podziemie 1939-1941. Red. Zuzanna Gajowniczek i in. T. 1: Lwów-Kołomyja-Stryj-Złoczów, Warszawa-Kijów 1998.

List Romana Stanisława Ingardena do Romana Witolda Ingardena, Lwów, 16 marca 1945 roku. W: ARI.

List Romana Witolda Ingardena do Romana Stanisława Ingardena, Kraków, 7 lutego 1945 roku. W: ARI. 
Mańkowski Tadeusz. Biblioteka Ossolineum w latach 1939-1944. W: Zakład Narodowy im. Ossolińskich, sygn. rkps. 17061/II, 14.

Mańkowski Tadeusz. „Ossolineum pod rządami sowieckimi”. Oprac. Maciej Matwijów. Czasopismo Zakładu Narodowego im. Ossolińskich 1 (1992): 144, przyp. 11.

Matwijów Maciej. 1996. Walka o lwowskie dobra kultury w latach 1945-1948, „Część II: Wybór dokumentów". Wrocław: Towarzystwo Przyjaciół Ossolineum, 159-308.

Matwijów Maciej. 2003. Zakład Narodowy imienia Ossolińskich w latach 1939-1946. Wrocław: Towarzystwo Przyjaciół Ossolineum.

Memoriał Polskiej Akademii Umiejętności do prezydenta Krajowej Rady Narodowej Bolesława Bieruta „w sprawie repatriacji archiwów, bibliotek oraz muzeów naukowo-artystycznych ze Lwowa i Wilna". Kraków [przed 19 października 1945].

Projekt memoriału Polskiej Akademii Umiejętności „W sprawie obrony zbiorów Ossolineum we Lwowie i innych zabytków kulturalnych polskich na wschodzie" [Kraków po 10 października 1945].

Protokół posiedzenia Komitetu PAU, 31 VIII 1945 (brulion), Archiwum Nauki PAN i PAU, KSG PAU 481/1945.

Sierżęga Paweł. 2011. Kazimierz Tyszkowski (1894-1940). Z dziejów nauki polskiej w międzywojennym Lwowie. Rzeszów: Wydawnictwo Uniwersytetu Rzeszowskiego.

Tytko Marek M. 2014. „Mjr prof. Stefan Szuman w walce o niepodległość Polski (1939-1945)". Sowiniec 44: 66.

Uchwała Rady Komisarzy Ludowych Ukraińskiej SRR nr 1673 w sprawie przekazania Tymczasowemu Rządowi Jedności Narodowej RP polskiego mienia kulturalnego. Kijów, 18 października 1945.

\section{Streszczenie}

Artykuł ten jest wprowadzeniem do rozpoznania manuskryptów i książek znajdujących się w Archiwum Rodzinnym Ingardenów. Przedstawiamy w nim dzieje tych archiwalnych dokumentów. Wplecione są one bezpośrednio w życie Romana Witolda Ingardena, okoliczności jego zatrudnienia we Lwowie, lata wojny, a także ostatnie lata życia w Krakowie.

Słowa kluczowe: Roman Witold Ingarden, dzieje manuskryptów i księgozbioru, rewindykacja.

\section{Summary}

The article is an introduction to the Roman Witold Ingarden collection forming the main part of the Ingarden Family Archive. The history of the collection has been presented. The fate of the papers and books by Ingarden was interwoven 
with the philosopher's life and career, the circumstances of his employment in Lviv, the war years and the last years of his life in Krakow. Currently, a part of the collection is stored as a separate fond in the Archive of Science of Polish Academy of Sciences and Polish Academy of Arts and Sciences. Most of the books had been handed over to the Library of Polish Academy of Sciences and Polish Academy of Arts and Sciences.

Keywords: Roman Witold Ingarden, philosophy, phenomenology, archives, manuscript collection. 